\title{
Thyroid Hormone-Inducible Hepatic Protein
}

National Cancer Institute

\section{Source}

National Cancer Institute. Thyroid Hormone-Inducible Hepatic Protein. NCI Thesaurus.

Code C117175.

Thyroid hormone-inducible hepatic protein (146 aa, $17 \mathrm{kDa}$ ) is encoded by the human

THRSP gene. This protein plays a role in lipogenesis. 